\title{
Prolactin Modulates TRPV1 in Female Rat Trigeminal Sensory Neurons
}

\author{
Anibal Diogenes, ${ }^{1}$ Amol M. Patwardhan, ${ }^{1}$ Nathaniel A. Jeske, ${ }^{2}$ Nikita B. Ruparel, ${ }^{3}$ Vincent Goffin, ${ }^{4}$ Armen N. Akopian, ${ }^{2}$ \\ and Kenneth M. Hargreaves ${ }^{1,2}$ \\ Departments of ${ }^{1}$ Pharmacology, ${ }^{2}$ Endodontics, and ${ }^{3}$ Cellular Structural Biology, University of Texas Health Science Center at San Antonio, San Antonio, \\ Texas 78229, and ${ }^{4}$ Université Paris Descartes, Faculté de Médecine, Le Site de l'Hôpital Necker, Institut National de la Santé et de la Recherche Médicale, \\ Unité 808, F-75015 Paris, France
}

Sex dependency in pain perception is well documented and is thought to be attributable to the effect of reproductive hormones on nociceptive processing. In the present study, we evaluated whether estradiol alters gene transcription in the trigeminal ganglia (TG) of ovariectomized rats (OVX). These experiments demonstrated a dramatic (40-fold) upregulation of prolactin (PRL) expression in TG by $17-\beta$-estradiol (E2). PRL expression was restricted to TG neurons and was highly overlapped with transient potential receptor vanilloid type 1 (TRPV1) ( $\sim 90 \%)$ in TG. Additionally, PRL is released from neurons during stimulation. Both forms of PRL receptors (PRLRs), short and long, were also present in TG neurons. Moreover, expression of the long PRLRs was under control of estradiol. We next evaluated the novel hypothesis that PRL acts as a neuromodulator of sensory neurons. PRL pretreatment significantly enhanced capsaicin-evoked inward currents, calcium influx, and immunoreactive calcitonin gene-related peptide release from cultured TG neurons. This PRL modulation of capsaicin responses was abolished by withdrawal of E2 from TG cultures. Biochemical analysis demonstrated that PRL increased ( $>50 \%$ ) phosphorylation levels of TRPV1 in TG. In a behavioral test, PRL pretreatment significantly potentiated capsaicin-evoked nocifensive behavior in female rats at proestrous and in OVX rats after E2 treatment. The in vivo potentiating effect of PRL on capsaicin responses was also dependent on E2. Collectively, these data demonstrate that PRL is a novel modulator of sensory neurons tightly regulated by E2. These findings are consistent with the hypothesis that PRL could contribute to the development of certain pain disorders, possibly including those modulated by estrogen.

Key words: prolactin; neuropeptide; prolactin receptor; antagonist; estradiol; estrogen; trigeminal; nociceptor; TRPV1; eye-wipe; capsaicin; heat; pain

\section{Introduction}

Numerous studies have demonstrated that certain pain disorders occur with higher prevalence, intensity, or duration in women than in men. Patient sex appears to be a risk factor for several trigeminal pain disorders, including temporomandibular disorders (Warren and Fried, 2001), trigeminal neuralgia (Katusic et al., 1990), pain after oral surgery (Gear et al., 1996), and migraine (Martin et al., 2003). Moreover, several of these conditions are exacerbated during the menstrual cycle or during episodes of altered circulating levels of estrogens or other steroids (Somerville, 1975; LeResche, 1997; Isselee et al., 2001, 2002).

Estrogen has been shown to exert its effects through genomic and nongenomic mechanisms (Toran-Allerand et al., 1999;

\section{Received Feb. 21, 2006; revised June 26, 2006; accepted June 27, 2006.}

This work was supported in part by a University of Texas Health Science Center at San Antonio (UTHSCSA) (San Antonio, TX) Presidential Research Enhancement Fund grant and the President's Council Endowed Chair in Research. We thank Dr. A. F. Parlow (National Hormone and Peptide Program, Harbor-University of California, Los Angeles, Torrance, (A), Dr. Carmen Hinojosa, Gaby Helesic, and Griffin Perry for technical assistance. We thank Dr. Michael Henry for acquiring the confocal images. The Affymetrix analysis was conducted by Drs. Chris Jenkenson and Dawn Richardson of the UTHSCSA Microarray Core.

Correspondence should be addressed to Dr. Kenneth M. Hargreaves, University of Texas Health Science Center at San Antonio, 7703 Floyd Curl Drive, San Antonio, TX 78229-3900. E-mail: hargreaves@uthscsa.edu.

DOI:10.1523/JNEUROSCI.0793-06.2006

Copyright $\odot 2006$ Society for Neuroscience $\quad$ 0270-6474/06/268126-11\$15.00/0
Purves-Tyson and Keast, 2004). Estrogen receptors are known to be expressed in the rat trigeminal ganglia (TG) (Bereiter et al., 2005), and their activation alters the expression of certain genes in sensory neurons (Sohrabji et al., 1994; Allen and McCarson, 2005). In the exploratory research phase of this study, we used cDNA microarray technology to investigate the effect of estrogen on the expression of gene transcripts in the TG of ovariectomized rats and discovered that prolactin (PRL) underwent the greatest upregulation in expression.

Prolactin, typically a $23 \mathrm{kDa}$ peptide hormone, is classically known to be produced and secreted from the anterior pituitary gland and to induce lactation in females (Riddle et al., 1933). Additionally, PRL is expressed in several extrapituitary tissues (Ben-Jonathan et al., 1996; Goffin et al., 1999; Freeman et al., 2000). Extrapituitary PRL is capable of activating local PRL receptors (PRLRs) in a paracrine or autocrine manner (Llovera et al., 2000; Ben-Jonathan et al., 2002; Clevenger, 2003). There are two natural PRLR isoforms in the rat, composed of 291 (short form) and 591 (long form) amino acids, generated by alternative splicing of the same gene (Boutin et al., 1988; Shirota et al., 1990). Most of the known PRL actions are attributed to the activation of the long PRLR (Bole-Feysot et al., 1998). The long PRLR primarily activates the Janus kinase/signal transducer and the activator 
of transcription 5 (Bole-Feysot et al., 1998). However, the long PLRR can also trigger other signaling pathways, including protein kinase C (PKC) and phosphatidylinositol 3'-kinase (PI3K) (Bole-Feysot et al., 1998; Clevenger and Kline, 2001). Importantly, the activation of PKC (Cesare et al., 1999; Vellani et al., 2001) and PI3K (Bonnington and McNaughton, 2003; Zhuang et al., 2004) has been implicated in the hyperalgesia mediated by activation of the capsaicin (CAP)-sensitive transient potential receptor vanilloid type 1 (TRPV1) expressed on a major subclass of nociceptors (Caterina et al., 1997)

Thus, there were two phases to the present study. In the exploratory phase, we used cDNA microarray technology to identify genes regulated by estrogen in sensory neurons of female rats. In the second phase, we evaluated the hypothesis that PRL is a modulator of capsaicin and heat-evoked responses in TG.

\section{Materials and Methods}

Animals. Adult ovariectomized (OVX) female Sprague Dawley rats and intact females (200-250 g; Charles River Laboratories, Wilmington, MA) were used in this study. All animal study protocols were approved by the Institutional Animal Care and Use Committee of the University of Texas Health Science Center at San Antonio and conformed to the International Association for the Study of Pain and federal guidelines. Animals were housed for 1 week before the experiments with food and water available ad libitum, and the OVX rats were used 2-3 weeks after their surgery.

Determination of reproductive cycle. The reproductive stage of cycling females was determined by vaginal lavage using sterile isotonic saline at the same time each day for at least three consecutive cycles $(\sim 12 \mathrm{~d})$ using methods described previously (Marcondes et al., 2002). Animals that were at the proestrous reproductive cycle stage were immediately decapitated, and TG were harvested and used for subsequent studies.

Materials. For in vivo studies, $17-\beta$-estradiol-3-benzoate (E2) (Sigma, St. Louis, MO) was dissolved in peanut oil (Sigma) at final concentrations to give systemic doses of 2,20, or $80 \mu \mathrm{g} / \mathrm{kg}$ in a $200 \mu \mathrm{l}$ injection volume. For in vitro studies, water-soluble $\beta$-estradiol (E2) (Sigma) was dissolved in water and diluted in culture media (final concentration of 50 $\mathrm{nm}$ ). CAP (Sigma) was dissolved in ethanol and diluted in saline for the behavioral studies and was diluted in buffer [HBSS or standard external solution (SES)] for the in vitro studies. Ovine PRL, kindly provided by Dr. A. F. Parlow (National Hormone and Peptide Program, HarborUniversity of California, Los Angeles, Torrance, CA), was dissolved in 5 $\mu \mathrm{M}$ sodium bicarbonate solution and diluted into buffer (HBSS or SES) for the in vitro studies or diluted in saline for the behavioral experiments. The PRL receptor antagonist $\Delta 1-9-$ G129R-hPRL was synthesized as described previously (Bernichtein et al., 2003; Goffin et al., 2005) and purified by HPLC; it was dissolved in $5 \mu \mathrm{m}$ sodium bicarbonate solution and diluted in SES buffer.

Estradiol administration. Ovariectomized rats received a daily subcutaneous injection of 2,20 , or $80 \mu \mathrm{g} / \mathrm{kg} 17$ - $\beta$-estradiol-3-benzoate in peanut oil $(200 \mu \mathrm{l})$ or vehicle for $10 \mathrm{~d}$. The 2,20 , or $80 \mu \mathrm{g} / \mathrm{kg}$ dose paradigms generated plasma estradiol levels of $1.89 \pm 0.36,59 \pm 17.1$, and $110 \pm 36.6 \mathrm{pg} / \mathrm{ml}$ (mean $\pm \mathrm{SEM} ; n=4$ per group), respectively (A. Diogenes and J. C. Fehrenbacher, unpublished observations). At the end of the 10th day, animals were used for behavioral experiments or killed by decapitation, and the TG of each individual animal were harvested. Harvested tissue was used for RNA isolation, total protein isolation, or preparing primary cultures of TG neurons.

RNA isolation. Harvested TG tissue from OVX (treated with vehicle or estradiol) or intact proestrous female rats were immediately frozen in liquid nitrogen and ground in a prechilled mortar. The ground tissue was used to isolate total RNA by the guanidinium thiocyanate method as described previously (Chomczynski and Sacchi, 1987). The isolated RNA was then treated with a DNA-free reagent (DNase I; Ambion, Austin, TX) and submitted to the Microarray Core Facility at the University of Texas Health Science Center at San Antonio. Additional RNA sample aliquots were used as template for the quantitative real-time reverse transcription (qRT)-PCR experiments.

Microarray analysis: target preparation, hybridization, staining, scanning, and analysis of image. RNA samples derived from TG of OVX rats treated with a single dose $\left(80 \mu \mathrm{g} \cdot \mathrm{kg}^{-1} \cdot \mathrm{d}^{-1}\right)$ of E2 or vehicle $(n=5$ for each group) were prepared for hybridization to Affymetrix (Santa Clara, CA) RG-U34A arrays according to the instructions of the manufacturer. Total RNA was used as a template for double-stranded cDNA synthesis (Superscript Double-Stranded cDNA Synthesis kit; Invitrogen, Carlsbad, CA), which was used as a template for biotin-labeled cRNA synthesis (Enzo BioArray High Yield RNA Transcription Labeling kit; Affymetrix). Purified (RNeasy kit; Qiagen, Valencia, CA) labeled cRNA was hybridized to the rat genomic RG-U34A GeneChips for $16 \mathrm{~h}$ at $45^{\circ} \mathrm{C}$. After hybridization, the probe arrays were washed and stained using the GeneChip Fluidics station protocol EukGE-ES2. The intensity of bound dye was measured with an argon laser confocal scanner (GeneArray Scanner; Agilent, Palo Alto, CA). The probe arrays were scanned twice, and the stored images were aligned and analyzed using the GeneChip software Microarray Analysis Suite 5.0 (Affymetrix). Data were imported into the GeneSpring 5.1 software (Silicon Genetics, Redwood City, CA), and a list of genes of relative expression of $\geq 1$. 5 -fold and $\leq 0.5$-fold was obtained. The data were imported into the $\mathrm{R}$ software package (http://www. r-project.org), and the probe level data were converted to expression measures using the Affymetrix package (Bolstad et al., 2003) from Bioconductor. Expression values for each mRNA were obtained by the robust multi-array analysis method as described previously (Bolstad et al., 2003). Cell intensity (CEL) files were normalized together, and the expression values obtained were further analyzed with the Statistical Analysis of Microarrays (SAM) software (Tusher et al., 2001) to identify those genes that were significantly increased or decreased. Only those genes that were found to be changed in both the GeneSpring and SAM analyses (i.e., concordant increasers or decreasers) were considered for additional analysis.

qRT-PCR. Total RNA (100 ng) was used as template in a one-step RT-PCR protocol. Amplification of target sequences was detected by a sequence detector ABI 7700 (Applied Biosystems, Foster City, CA) using TaqMan Gene Expression Assays on Demand (Applied Biosystems, Foster City, CA) using specific primers and probes for the selected genes (PRL, assay number Rn00561791_m1; 12-lipoxygenase, assay number Rn00578743_m1; TrkA, assay number Rn00572130_m1; interleukin-1 $\alpha$, assay number Rn00566700_m1; nuclear receptor subfamily 1 group D member 1, assay number Rn00595671_m1; eukaryotic 18S rRNA endogenous reference, assay number Hs99999901_s1).

The reactions were run in triplicates of $25 \mu \mathrm{l}$, containing the respective TaqMan Gene Expression Assay on Demand and TaqMan Universal PCR Master Mix (Applied Biosystems). For each individual gene expression assay, the endogenous control, $18 \mathrm{~S}$ ribosomal subunit, gene expression assay was also run in triplicate. The comparative $\Delta \Delta \mathrm{Ct}$ was used to normalize the data based on the endogenous reference and to express it as the relative fold change after the exclusion criteria were verified by comparing primer efficiencies (Livak and Schmittgen, 2001).

Rat TG primary cultures. The TG from ovariectomized or intact female rats were quickly removed after decapitation, and neuronal cultures were prepared as described previously (Fehrenbacher et al., 2005; Patwardhan et al., 2005). The trypsin treatment was omitted in TG cultures prepared for electrophysiological recording and $\mathrm{Ca}^{2+}$ imaging. Cells were plated on 24-well poly-D-lysine-coated plates [for immunoreactive calcitonin gene-related peptide (iCGRP) experiments], six-well poly-D-lysinecoated plates (for PRL release experiments), poly-D-lysine/laminincoated coverslips (for single-cell studies), or $10 \mathrm{~cm}$ plates (for phosphorylation experiments), respectively. The TG cultures were maintained at $37^{\circ} \mathrm{C}$ and $5 \% \mathrm{CO}_{2}$. For the calcium imaging and electrophysiology experiments, cells were plated as two ganglia per plate and grown for $2-8 \mathrm{~h}$ in culture in the presence of either $50 \mathrm{~nm}$ water-soluble estradiol or vehicle. For the CGRP and PRL release experiments, cells were plated at six ganglia per plate and grown for $5 \mathrm{~d}$ in culture in the presence of 100 ng/ml NGF (Harlan, Indianapolis, IN) and either 50 nm water-soluble estradiol (Sigma) or vehicle. The media were replaced at the end of $24 \mathrm{~h}$ and then $48 \mathrm{~h}$ later. 
Table 1. Effect of estradiol administration ( $80 \mu \mathrm{g} / \mathrm{kg}$ for $10 \mathrm{~d}$ ) versus vehicle on gene expression in trigeminal ganglia of ovariectomized rats as assessed by Affymetrix microarray

\begin{tabular}{|c|c|c|c|c|}
\hline Gene name & Probe set ID number & NCBI accession number & $\mathrm{SAM}^{a}$ & $\mathrm{GS}^{a}$ \\
\hline \multicolumn{5}{|l|}{ Concordant increasers } \\
\hline Prolactin & E03166cds_s_at & NM_012629 & 6.9 & $\geq 1.5$ \\
\hline Prolactin & V01244_at & NM_012629 & 12.8 & $\geq 1.5$ \\
\hline Prolactin & V01250cds_s_at & NM_012629 & 3 & $\geq 1.5$ \\
\hline TrkA 3' mRNA sequence & AA958274_at & AA958274 & 1.5 & $\geq 1.5$ \\
\hline Histidine ammonia lyase & AB002393_at & NM_017159 & 1.5 & $\geq 1.5$ \\
\hline Ania-10 early gene mRNA, $3^{\prime}$ UTR & AF050662UTR\#1_at & NM_031593 & 1.6 & $\geq 1.5$ \\
\hline Ania-12 early gene mRNA, 3' UTR & AF050664UTR\#1_at & XM_220080 & 1.5 & $\geq 1.5$ \\
\hline Insulin receptor substrate 2 (IRS-2) mRNA & AF087674_at & XM_573948 & 1.4 & $\geq 1.5$ \\
\hline Interleukin $1 \alpha$ & D00403_g_at & NM_017019 & 1.3 & $\geq 1.5$ \\
\hline Aldosterone synthase, exon 9 & D14097cds_s_at & NM_012537 & 1.5 & $\geq 1.5$ \\
\hline Cytochrome P450, 3a18 & D38381_s_at & NM_145782 & 1.3 & $\geq 1.5$ \\
\hline Prepro bone inducing protein & D49494cds_s_at & NM_024375 & 1.3 & $\geq 1.5$ \\
\hline Nuclear receptor subfamily 1, group D, member 1 & M25804_g_at & NM_145775 & 1.5 & $\geq 1.5$ \\
\hline Cytochrome P450, 1a2 & M26127_s_at & NM_012541 & 1.3 & $\geq 1.5$ \\
\hline Interleukin 5 (colony-stimulating factor, eosinophil) & X54419cds_at & NM_021834 & 1.3 & $\geq 1.5$ \\
\hline Cytosolic epoxide hydrolase & X60328_at & NM_022936 & 1.7 & $\geq 1.5$ \\
\hline Similar to Mus musculus pre 455 pre rRNA gene & rc_AA859966_i_at & AA859966 & 4.1 & $\geq 1.5$ \\
\hline Cytochrome P450, subfamily IIC6 & rc_AA945571_s_at & NM_001013904 & 1.7 & $\geq 1.5$ \\
\hline \multicolumn{5}{|l|}{ Concordant decreasers } \\
\hline Arachidonate 12-lipoxygenase & S69383_at & NM_031010 & 0.5 & $\leq 1.5$ \\
\hline Protein phosphatase 3 , catalytic subunit, $\beta$ isoform & M31809_at & NM_017042 & 0.6 & $\leq 1.5$ \\
\hline Electron transf. flavoprotein (Etfa), mRNA & rC_AA894174_at & NM_001009668 & 0.7 & $\leq 1.5$ \\
\hline
\end{tabular}

${ }^{a}$ Affymetrix microarray experiment was performed with TG RNA isolated from vehicle-treated or E2-treated ( $80 \mu \mathrm{g} / \mathrm{kg}$ for $10 \mathrm{~d}$ ) rats ( $n=5$ per group). Results were individually analyzed by two independent methods: statistical analysis of microarrays (SAM) and GeneSpring 5.1 (GS). There were 18 genes found to be upregulated in both analyses (concordant increasers), and three genes were found to be downregulated in both analyses (concordant decreasers). Data are presented as means with false discovery rate of $10 \%$ for SAM and change cutoff for the GS. UTR, Untranslated region.

Immunohistochemistry. Rat tissue cryosections or cultured TG cells were fixed with $4 \%$ formaldehyde, permeabilized with $0.5 \%$ Triton $\mathrm{X}-100$, and then blocked with $10 \%$ normal goat serum (30 min each step). Cells or tissue slides were then incubated overnight at $4^{\circ} \mathrm{C}$ with a rabbit polyclonal antibody directed against PRL (1:5000), kindly provided by Dr. A. F. Parlow or mouse monoclonal anti-PRLR antisera (1:500; clone U5; Affinity BioReagents, Golden, CO) (De Petrocellis et al., 1998; Shingo et al., 2003) and a guinea pig anti-TRPV1 antisera (1: 3000; Neuromics, Bloomington, MN). Immunoreactivity was detected using an appropriate secondary antibody conjugated to Alexa- 488 or Alexa-594 conjugated (1:500; Invitrogen). Images were acquired using a Nikon (Melville, NY) E600 microscope. Images were analyzed using MetaMorph software (version 4.5 r6; Universal Imaging Corporation, West Chester, PA), and the percentages of PRL and PRLR colocalization with TRPV1 for each condition were determined by manually counting the number of cells with double labeling in a $20 \times$ magnification view field.

$P R L$ release experiments. These experiments were performed at day 5 with TG cultures from OVX or intact female rats using Krebs' buffer (135 $\mathrm{mm} \mathrm{NaCl}, 3.5 \mathrm{~mm} \mathrm{KCl}, 1 \mathrm{~mm} \mathrm{MgCl}_{2}, 1 \mathrm{~mm} \mathrm{NaH} \mathrm{PO}_{4}, 2.5 \mathrm{~mm} \mathrm{CaCl}$, $0.1 \%$ BSA, $3.3 \mathrm{~mm}$ dextrose, $0.1 \mathrm{~mm}$ ascorbic acid, $10 \mathrm{~mm}$ HEPES, and 16 $\mu \mathrm{M}$ thiorphan, $\mathrm{pH}$ 7.4). After two initial washes, a $15 \mathrm{~min}$ baseline sample was collected. Cells were then exposed to $300 \mathrm{~nm}$ capsaicin (Sigma) or 25 $\mathrm{mm} \mathrm{KCl}$ and incubated at $37^{\circ} \mathrm{C}$ for an additional $15 \mathrm{~min}$, followed by collection of the samples. The $1 \mathrm{ml}$ collected samples were lyophilized and resuspended in $250 \mu \mathrm{l}$ of water and immediately frozen in $-80^{\circ} \mathrm{C}$. Frozen samples were sent to Dr. A. F. Parlow to have levels of PRL determined by a well validated radioimmunoassay (RIA) with a sensitivity range from 1 to $100 \mathrm{ng} / \mathrm{ml}$. Results are representative of six independent experiments.

Calcium imaging. TG cells cultured on coverslips were loaded with the cell-permeable calcium-sensitive dye fura-2 AM ( $1 \mu \mathrm{g} / \mathrm{ml})$ (Invitrogen) for $30 \mathrm{~min}$ at $37^{\circ} \mathrm{C}$ in SES of the following composition (in mM): 140 $\mathrm{NaCl}, 5 \mathrm{KCl}, 2 \mathrm{CaCl}_{2}, 1 \mathrm{MgCl}_{2}, 10$ glucose, and 10 HEPES, pH 7.4. Coverslips containing cells were placed in a chamber with constant infusion of SES. Images were detected by a Nikon Eclipse TE-2000 microscope fitted with a $20 \times /$ numerical aperture 0.75 Fluor objective. Fluorescence images were collected in $5 \mathrm{~s}$ intervals throughout the experiment

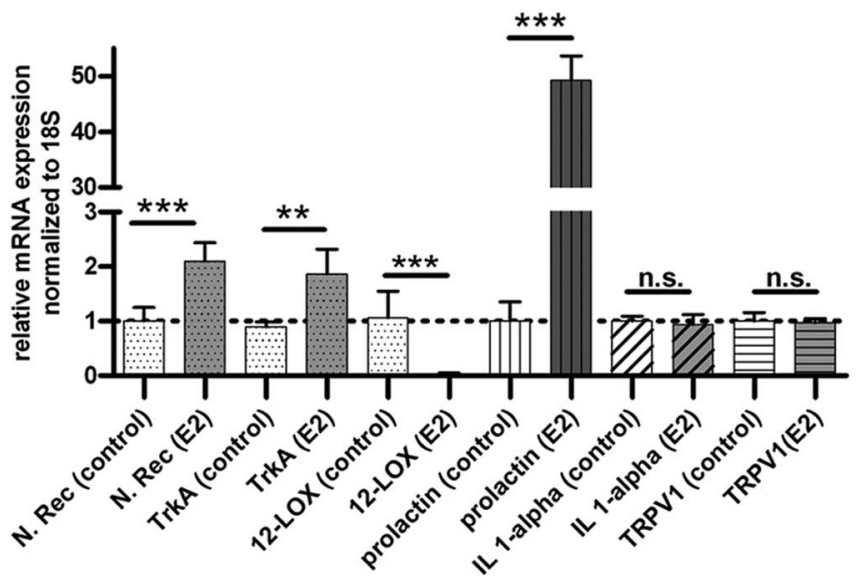

Figure 1. Validation of CDNA microarray data. Selected genes from the Affymetrix experiment were further analyzed by real-time RT-PCR. Validated primers were used for each gene, and expression was normalized to the housekeeping gene $18 \mathrm{~S}$. Data are presented as mean \pm SEM $\left(n=5\right.$ per group; ${ }^{* *} p<0.01$ and ${ }^{* * *} p<0.001$ vs respective vehicle control, two-tailed unpaired $t$ test). N. Rec, Nuclear receptor subfamily 1, group D, member 1; 12-LOX, 12-lipoxygenase; IL 1- $\alpha$, interleukin-1 $\alpha$; n.s., not significant.

and analyzed, and the $F_{340} / F_{380}$ ratio was calculated by the Metafluor software (MetaMorph; Universal Imaging Corporation). Capsaicin was delivered locally to the cells, whereas PRL was delivered into the bath solution. The magnitude of calcium influx was determined by subtracting the averaged baseline $30 \mathrm{~s}$ before the capsaicin stimulus from the peak achieved by the capsaicin stimulation for each cell (ratiometric method, $\left.\Delta F_{340} / F_{380}\right)$.

Patch-clamp electrophysiology. All recordings were performed in whole-cell voltage-clamp $\left(V_{\mathrm{h}}\right.$ of $\left.-60 \mathrm{mV}\right)$ configuration. Recordings were made at $22-24^{\circ} \mathrm{C}$ from the somata of neurons $(15-45 \mathrm{pF})$ using an Axopatch 200B amplifier and pClamp 9.0 software (Molecular Devices, Palo Alto, CA). Cell diameters were calculated using $d=\sqrt{ }\left(100{ }^{\star} C_{\mathrm{m}} / \pi\right)$, where $d$ (micromolar) is cell diameter, and $C_{\mathrm{m}}$ (picofarads) is membrane 

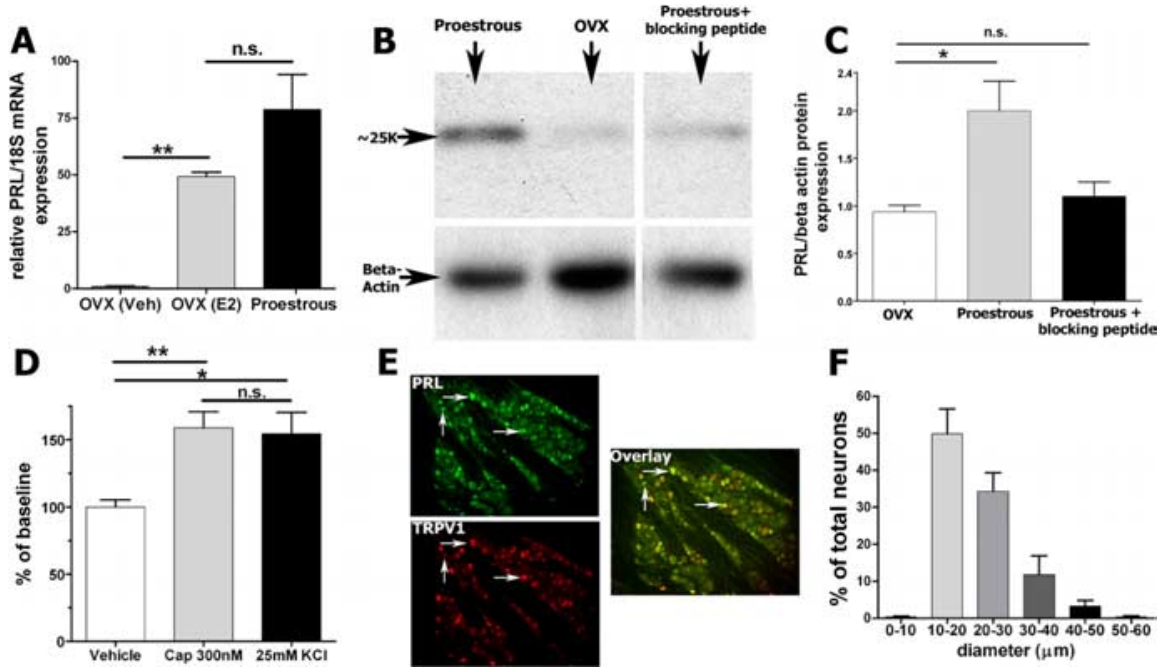

$\mathbf{E}$
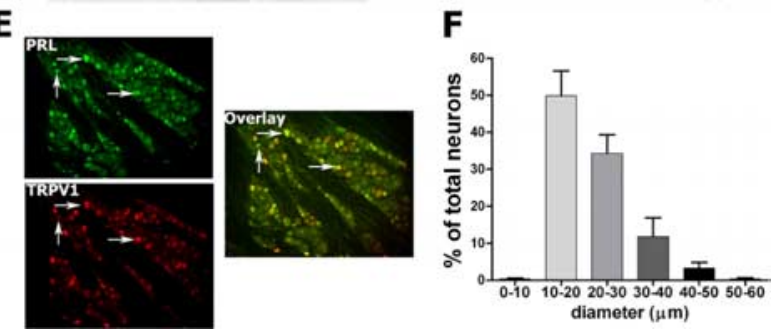

Figure 2. Estrogen regulates PRL expression in TG neurons. $\boldsymbol{A}$, Real-time RT-PCR experiments were performed with TG RNA samples from proestrous female rats and OVX female rats pretreated with either vehicle or estradiol $\left(80 \mu \mathrm{g} \cdot \mathrm{kg}^{-1} \cdot \mathrm{d}^{-1}\right.$ for $10 \mathrm{~d}$ ). Reactions were performed using primers specific for PRL gene and the internal control (18S). Data were normalized to the relative amount of OVX (vehicle) PRL mRNA/18S. Data are presented as mean \pm SEM ( $n=5$ per group; ${ }^{* *} p<0.01$ vs PRL mRNA of the OVX/vehicle group, one-way ANOVA with Bonferroni's post hoc test). $\boldsymbol{B}$, Representative immunoblot of TG protein extracts. PRL was detected as a single band migrating at $\sim 25 \mathrm{kDa}$. Proteins were separated by $12.5 \%$ SDS-PAGE and probed with an antibody against PRL. Incubation of the antibody with the control peptide $(20 \times)$ significantly blocked the immunoreactivity seen in TG protein samples from proestrous rats. C, Quantification of immunoblots of TG protein extracts from OVX rats injected with estradiol $(2-80 \mu \mathrm{g} / \mathrm{kg})$. Proteins were separated in $12.5 \%$ SDS-PAGE and probed with an antibody against PRL. Data are presented as mean \pm SEM $\left(n=4\right.$ per group; $\left.{ }^{*} p<0.05\right)$. $D$, Release of immunoreactive PRL from cultured TG neurons harvested from intact female rats. Data are presented as mean \pm SEM percentage of basal release $\left(n=6\right.$ per group; ${ }^{*} p<0.05$ and ${ }^{* *} p<$ 0.01 , one-way ANOVA with Bonferroni's post hoc test). $\boldsymbol{E}$, Immunohistochemistry was performed to demonstrate colocalization of PRL with TRPV1 (horizontal arrows) in the proestrous rat TG. Vertical arrow shows a PRL-positive neuron that is not positive for TRPV1. F, The cell size distribution of the immunoreactive PRL-containing neurons. Approximately, of all PRL-positive cells, 50\% were of small diameter $(0-20 \mu \mathrm{m}), 46.12 \%$ were of medium diameter $(20-40 \mu \mathrm{m})$, and $3.7 \%$ were of large diameter $(40-60$ $\mu \mathrm{m})$. The mean cell size was $21.4 \mu \mathrm{m}(n=1160)$. n.s., Not significant; Veh, vehicle.

capacitance. Data were filtered at $0.5 \mathrm{kHz}$ and sampled at $2 \mathrm{kHz}$. Borosilicate pipettes (Sutter Instruments, Novato, CA) were polished to resistances of 5-10 $\mathrm{M} \Omega$ in pipette solution. Access resistance was compensated $(40-80 \%)$ when appropriate.

SES had the composition as described above. The pipette solution had an estimated free $\mathrm{Ca}^{2+}$ concentration of $\sim 100 \mathrm{~nm}$ and consisted of the following (in mM): $140 \mathrm{KCl}, 1 \mathrm{MgCl}_{2}, 1 \mathrm{CaCl}_{2}, 10 \mathrm{EGTA}, 10 \mathrm{D}$-glucose, 10 HEPES, $0.2 \mathrm{Na}-\mathrm{GTP}$, and $2.5 \mathrm{Mg}$-ATP, pH 7.3. Drugs were applied using a fast, computer-controlled pressure-driven eight-channel system (ValveLink8; AutoMate Scientific, San Francisco, CA). For the heatactivation experiments, cells were treated with PRL or vehicle delivered in the bath solution. SES was progressively heated by a Peltier device (Warner Instruments, Hamden, CT) and locally delivered to the cells. The temperature in the vicinity of the cells was recorded by a thermister probe (Harvard Apparatus, Holliston, MA) coupled to an Axopatch 200B amplifier and pClamp 9.0 software (Molecular Devices) positioned in close proximity to the cell.

CGRP release assay. All culture experiments were performed on day 5 at $37^{\circ} \mathrm{C}$ using modified HBSS (Invitrogen) buffer (10.9 mM HEPES, 4.2 $\mathrm{mm}$ sodium bicarbonate, $10 \mathrm{~mm}$ dextrose, and $0.1 \%$ bovine serum albumin were added to $1 \times$ HBSS). After two initial washes, a $15 \mathrm{~min}$ baseline sample was collected. The cells then were exposed to either vehicle or PRL (Dr. A. F. Parlow) ( $40 \mathrm{~nm}$ ) for $15 \mathrm{~min}$ and then stimulated with capsaicin $(50 \mathrm{nM})$ for $15 \mathrm{~min}$. All of the treatments were collected for analysis of iCGRP content by RIA.

iCGRP RIA. A previously used (Garry et al., 1994) primary antibody against CGRP (final dilution of 1:1,000,000; kindly donated by Dr. M. J. Iadarola, National Institutes of Health, Bethesda, MD) was added in the tubes containing superfusate from cultured rat TG and incubated at $4^{\circ} \mathrm{C}$ for $24 \mathrm{~h}$. Then $100 \mu \mathrm{l}$ of [ $\left.{ }^{125} \mathrm{I}-\right]-\mathrm{Tyr}^{0}-\mathrm{CGRP}_{28-37}(\sim 20,000 \mathrm{cpm})$ and 50 $\mu \mathrm{l}$ of goat anti-rabbit antisera coupled to ferric beads (PerSeptive Diag- nostics, Cambridge, MA) were added to these tubes. The tubes were incubated for another $24 \mathrm{~h}$ at $4^{\circ} \mathrm{C}$. The assay was stopped using immunomagnetic separation of bound from free tracer. All compounds used in experiments were tested for interference with the RIA. The minimum detectable levels for CGRP for this assay are $\sim 3 \mathrm{fmol}$ and the $50 \%$ displacement at $28 \mathrm{fmol}$.

Immunoprecipitation and Western blot analysis. Total protein was isolated from harvested TG by tissue disruption in homogenization buffer consisting of $25 \mathrm{~mm}$ HEPES, $25 \mathrm{~mm} \mathrm{su}$ crose, $1.5 \mathrm{~mm} \mathrm{MgCl}_{2}, 50 \mathrm{~mm} \mathrm{NaCl}$, leupeptin (1 $\mu \mathrm{g} / \mathrm{ml})$, pepstatin $(1 \mu \mathrm{g} / \mathrm{ml})$, aprotinin $(2 \mu \mathrm{g} /$ $\mathrm{ml}$ ), and PMSF (100 nm), pH 7.2, using a prechilled mortar and pestle. Protein samples were resolved on $12.5 \%$ SDS-PAGE and transferred to polyvinylidene difluoride (PVDF) (Millipore, Billerica, MA), and the Western blots were blocked in 5\% BSA in TBS-Tween 20 and visualized using antibodies to PRL (1:2500; C-17; Santa Cruz Biotechnology, Santa Cruz, CA) or PRLR (1:500; clone U5; Affinity BioReagents) (De Petrocellis et al., 1998; Shingo et al., 2003), followed by appropriate secondary antisera linked to HRP and enhanced chemiluminescence (GE Healthcare, Piscataway, NJ) following the instructions of the manufacturer.

For protein phosphorylation experiments, $10 \mathrm{~cm}$ plates of TG, grown for $4-8 \mathrm{~h}$, were incubated with $1 \mathrm{mCi}$ of $\left[{ }^{32} \mathrm{P}\right]$ orthophosphate (PerkinElmer, Wellesley, MA) per plate for $4 \mathrm{~h}$ at $37^{\circ} \mathrm{C}$ in phosphate-free DMEM. Plates were treated with $40 \mathrm{~nm}$ PRL or vehicle $\left(\mathrm{H}_{2} \mathrm{O}\right)$ for 10 $\mathrm{min}$ and prepared for harvesting. After rigorous rinsing with $1 \times$ PBS and lysis in general lysis buffer (1 mM sodium pyrophosphate, $50 \mathrm{~mm}$ HEPES, pH 7.5, 1\% Triton X-100, $50 \mathrm{~mm} \mathrm{NaCl}$, $50 \mathrm{~mm} \mathrm{NaF}, 5$ mм EDTA, pH 8.0, 1 mm sodium orthovanadate, $1 \mu \mathrm{g} / \mathrm{ml}$ pepstatin, $1 \mu \mathrm{g} / \mathrm{ml}$ leupeptin, and $100 \mathrm{~nm}$ PMSF), cleared lysates were immunoprecipitated with $1 \mu \mathrm{g}$ of anti-TRPV1 (Calbiochem, San Diego, CA), resolved on 15\% SDS-PAGE, and transferred to PVDF (Millipore). Western blots were either exposed to film at $-80^{\circ} \mathrm{C}$ overnight for autoradiography or visualized as described above using anti-TRPV1 antisera (Calbiochem).

Autoradiography and Western blot results were scanned and quantified using NIH Image version 1.62. All autoradiographic bands were normalized to values obtained from total immunoprecipitated TRPV1. Results are representative of three to four independent experiments.

Eye-wipe test. OVX female rats, treated with either vehicle or E2 (5 $\mu \mathrm{g} / \mathrm{d}$ for $10 \mathrm{~d}$ ) or intact female rats in the proestrous reproductive stage were brought to a quiet, temperature-controlled $\left(22-25^{\circ} \mathrm{C}\right)$ behavioral laboratory in individual cages in which they were allowed to acclimate for at least $2 \mathrm{~h}$. PRL $(1 \mu \mathrm{g} / \mu \mathrm{l})$ or vehicle was placed directly onto the right eye in a volume of $40 \mu \mathrm{l}$, followed by application of $0.01 \%$ (40 $\mu \mathrm{l})$ capsaicin solution as described previously (Price et al., 2004). The resulting behavioral response was measured as time spent grooming or wiping the test eye. The observers were blinded to the treatments, and the data were collected in three bins of $5 \mathrm{~min}$.

Data analysis. All experiments were conducted with $n=8$ wells per group for culture experiments (CGRP, PRL release), $n=3-6$ tissue samples per group for qRT-PCR and immunoblotting experiments, and $n=6-8$ rats per group for behavioral experiments to determine the experimental observation and then repeated at least three times to conduct the statistical analysis. The iCGRP, PRL release, and calcium influx data are presented as percentage of basal levels (mean \pm SEM). Data were analyzed using Prism software version 4 (GraphPad Software, San Diego, $\mathrm{CA})$. The results were analyzed using one-way ANOVA, and individual 
groups were compared using a Bonferroni's post hoc test. Two-factor multiple treatment data were analyzed by two-way ANOVA, whereas data comparing only two groups were analyzed using two-tailed $t$ test. The statistical significance was tested at $p<0.05$.

\section{Results}

$17-\beta$-estradiol controls the gene expression in the trigeminal ganglia cells of ovariectomized rats

To identify estradiol-controlled genes involved in nociception in the rat TG, we performed Affymetrix microarray experiments with TG cDNA samples from OVX rats injected with estradiol or vehicle. The SAM and GeneSpring 5.1 analyses revealed 18 upregulated and three downregulated genes (Table 1). Genes were selected for additional analysis based on their known involvement in nociception (e.g., interleukin-1 $\alpha$, 12-lipoxygenase, TRPV1, and TrkA) or based on their maximal response to estradiol (e.g., PRL). Real-time RT-PCR on selected genes was conducted to confirm the findings and determine the magnitude of the changes (Fig. 1). The expression levels of these selected genes were in accordance with the microarray data, with the exception of interleukin- $1 \alpha$ that was a false positive (Table 1 vs Fig. 1). PRL was selected for additional studies because of its highly significant 48 -fold increase $(p<0.001)$ in expression level in female TG after estradiol treatment.

\section{PRL expression in trigeminal sensory neurons is regulated by estradiol}

We next performed a set of experiments to characterize the regulation of PRL mRNA and protein by either exogenous or endogenous estradiol. PRL mRNA levels were assessed by quantitative RT-PCR, and protein levels were quantified by immunoblot analysis from TG preparations isolated from OVX rats treated with vehicle, OVX rats treated with daily injections of estradiol $(80 \mu \mathrm{g} / \mathrm{kg}$ for $10 \mathrm{~d})$, and intact proestrous female rats. Figure $2 \mathrm{~A}$ illustrates that the PRL mRNA levels in the TG collected from OVX rats treated with estradiol replacement were $\sim 50$-fold greater $(p<0.01)$ compared with PRL mRNA from the TG of OVX control rats. Moreover, the relative PRL mRNA expression in the TG of intact female rats during proestrous was 78 -fold greater $(p<0.001)$. The TG samples collected from these groups were also subjected to Western blot analysis of the PRL protein. Immunoreactive PRL from TG migrates as a single band at $\sim 25$ $\mathrm{kDa}$, corresponding to the full-length PRL protein (Fig. $2 \mathrm{~B}$ ). The PRL protein level was significantly increased in the TG of proestrous rats compared with the OVX vehicle control rats (Fig. $2 B, C)$. The specificity of anti-PRL antibodies was evaluated by the use of the blocking peptide corresponding to the epitope of PRL. Preabsorption of anti-PRL with the blocking peptide nearly eliminated the PRL-specific band (Fig. $2 B, C$ ).

PRL is known to be released from cells of the anterior pituitary (Zacur et al., 1976) and from extrapituitary sites (Ben-Jonathan et al., 2002; Zinger et al., 2003; Torner et al., 2004). Therefore, we determined whether PRL protein is present in a releasable pool in TG sensory neurons. Cultured TG neurons derived from either proestrous rats (cultured in the presence of $50 \mathrm{nM}$ E2) or OVX rats (cultured without E2) were exposed to $300 \mathrm{nM}$ capsaicin or $25 \mathrm{~mm} \mathrm{KCl}$ buffer. A substantial amount of PRL was released from TG neurons of proestrous rats cultured in the presence of E2 during stimulation with either capsaicin $(158 \pm 12 \%$ of vehicle) or KCL $(154 \pm 16 \%$ of vehicle) (Fig. $2 \mathrm{D})$. In contrast, no detectable release of immunoreactive PRL was observed in neurons from OVX rats cultured in the absence of E2 (data not shown).

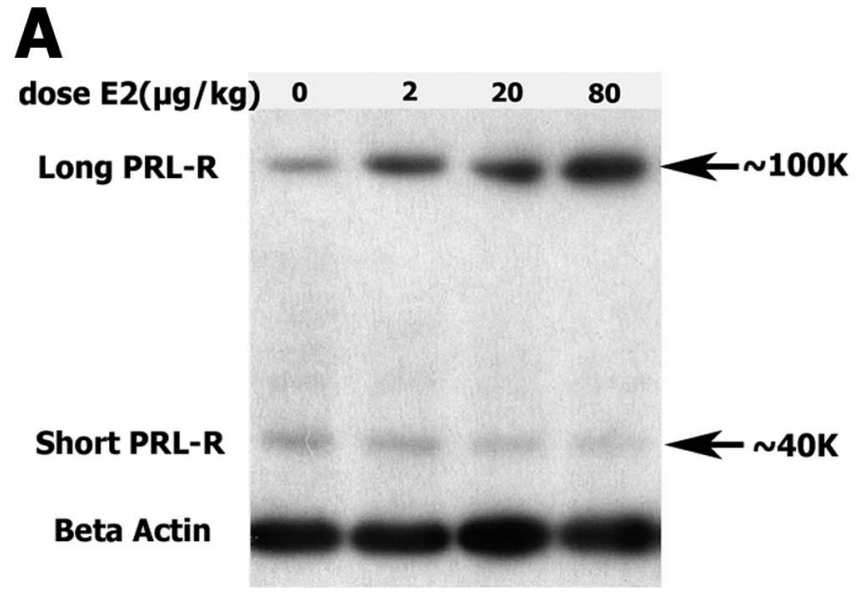

\section{B}
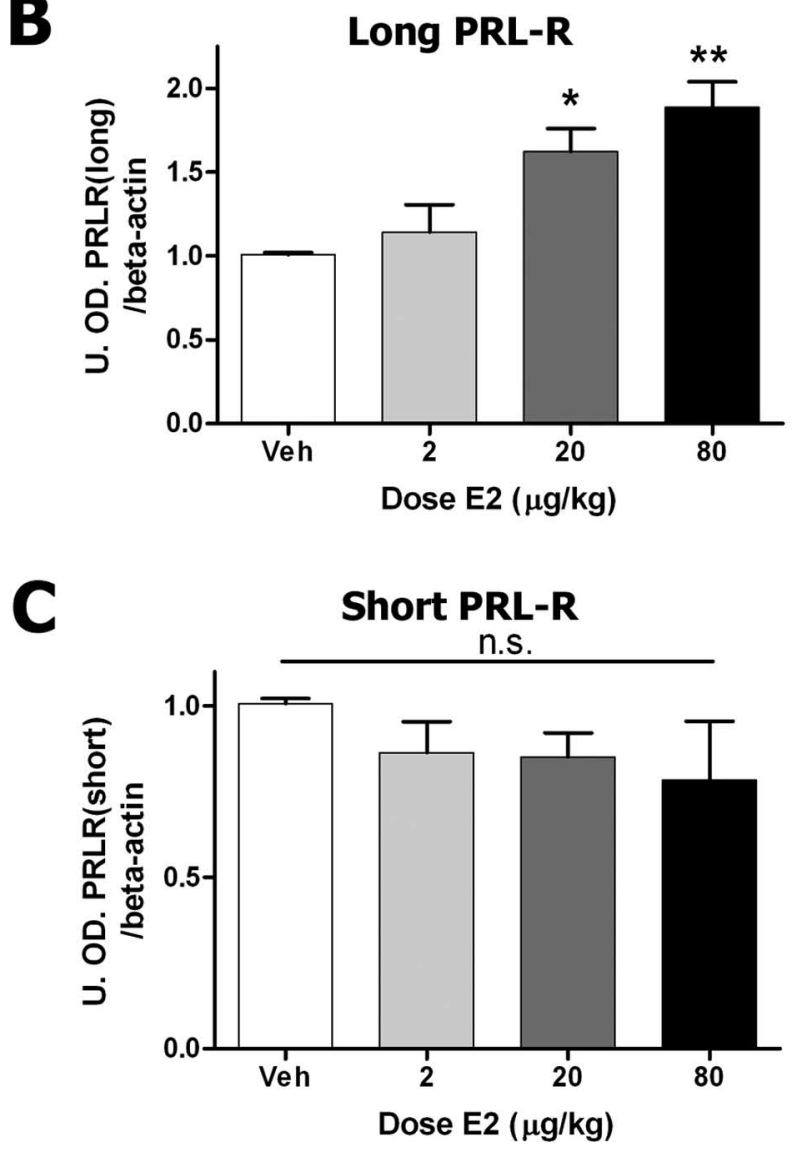

Figure 3. The expression of PRLR long form is regulated by estradiol. $\boldsymbol{A}$, Representative immunoblot. Proteins were separated in a $12.5 \%$ SDS-PAGE and probed with an antibody against PRLR. The antibody recognized two bands migrating at $\sim 100$ and $40 \mathrm{kDa}$, corresponding to the long and short PRLR isoforms, respectively. Blots were stripped and probed with an antibody against $\beta$-actin to normalize for loading differences. $B, C$, Quantification of immunoblots. TG proteins from OVX treated with E2 $(0,2,20$, or $80 \mu \mathrm{g} / \mathrm{kg})$ were separated in a $12.5 \%$ SDS-PAGE and probed with an antibody against PRLR. Data are presented as mean $\pm \operatorname{SEM}(n=$ 4 per group; ${ }^{*} p<0.05$ and ${ }^{* *} p<0.01$, one-way ANOVA with Bonferroni's post hoc test). U.OD., Uncalibrated OD; n.S., not significant; Veh, vehicle.

Prolactin is expressed by TRPV1-containing trigeminal neurons

Based on the observation that capsaicin evokes the release of PRL from TG cultures, we evaluated whether PRL is expressed in the TRPV1-positive subset of nociceptors. PRL protein was only ex- 


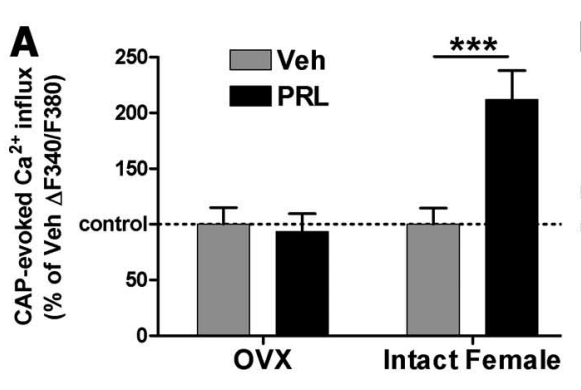

B
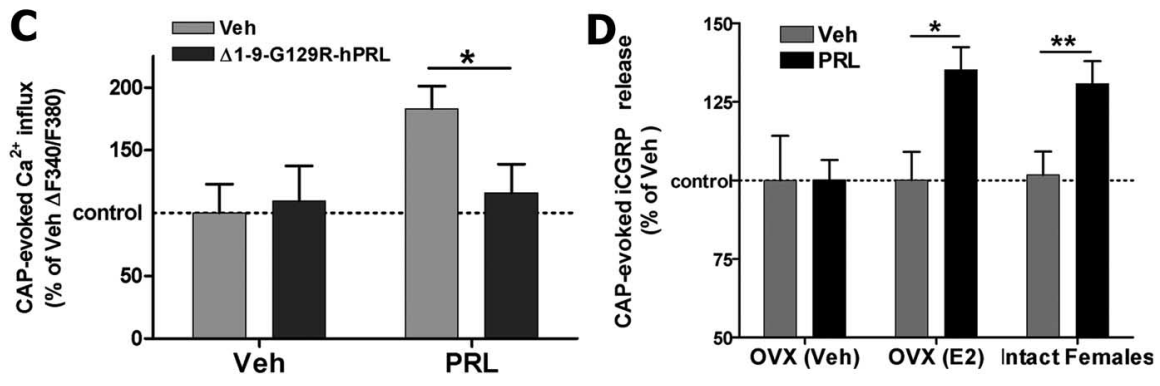

Figure 4. Prolactin augments capsaicin-evoked calcium influx in acutely cultured trigeminal ganglia neurons from intact female rats but not from OVX rats. $\boldsymbol{A}$, Results of $\mathrm{Ca}^{2+}$ imaging experiments performed in acutely dissociated TG neurons. Data are presented as mean \pm SEM percentage of vehicle ( $n=30$ per group; ${ }^{* * *} p<0.001$, two-way ANOVA). $\boldsymbol{B}$, Representative traces of $\mathrm{Ca}^{2+}$ imaging experiments performed in neurons from proestrous rats. Neurons were treated with $40 \mathrm{~nm}$ PRL or vehicle for 10 min, followed by a $40 \mathrm{~s}$ capsaicin ( $30 \mathrm{~nm}$ ) application. PRL did not evoke $\mathrm{Ca}^{2+}$ influx on its own but significantly potentiated capsaicin-evoked $\mathrm{Ca}^{2+}$ influx. Data are presented as mean $\pm \mathrm{SEM} F_{340} / F_{380}$ ( $n=8$ per group; error bars are SEM). C, Ca ${ }^{2+}$ imaging experiments performed in neurons from proestrous rats. Neurons were treated as described in the previous experiment (B). In addition, neurons were cotreated with PRL and the PRL receptor antagonist $\Delta 1-9-\mathrm{G} 129 \mathrm{R}-\mathrm{hPRL}$ (800 nm). The PRLR antagonist significantly blocked PRL potentiation of capsaicin-evoked $\mathrm{Ca}^{2+}$ influx, whereas it had no effect on its own. Data are presented as mean \pm SEM percentage of vehicle $\left(n=19-40\right.$; ${ }^{*} p<0.05$, two-way ANOVA). $\boldsymbol{D}$, iCGRP release experiments were performed with TG neurons from intact female and OVX rats cultured for $5 \mathrm{~d}$ in the presence of E2 ( $50 \mathrm{~nm}$ ) or vehicle. iCGRP was measured by radioimmunoassay. Data are presented as mean \pm SEM percentage of vehicle ( $n=4$ per group; ${ }^{*} p<0.05$ and ${ }^{* *} p<0.01$ vs iCGRP levels of each control group, two-tailed unpaired $t$ test). Veh, Vehicle.

pressed by neurons of the TG. Immunoreactive PRL was present in $35.1 \pm 1.5 \%$ (907 of 2591 neurons) of all proestrous rat TG neurons, whereas anti-TRPV1 labeled $\sim 31.6 \pm 1.4 \%$ (830 of 2591 neurons) of TG neurons. In addition, $90.3 \pm 2.0 \%$ (819 of 907 neurons) of the PRL-containing neurons were also positive for TRPV1 (Fig. 2E). PRL immunoreactivity was detected primarily in small-sized $(0-20 \mu \mathrm{m} ; 50 \%)$ and medium-sized (20-40 $\mu \mathrm{m} ; 46.12 \%)$ sensory neurons, with a mean diameter value of $21.4 \mu \mathrm{m}$ (Fig. $2 F$ ).

\section{The long form of the prolactin receptor expression is controlled by estradiol}

There are two isoforms of the rat PRLR that differ in the length of their cytoplasmic tail and are therefore termed the long and short isoforms. Most biological functions of the PRLR are attributed to the long form (Jabbour and Kelly, 1997), and the relative expression ratio of the long and short forms has been shown to be important in determining the responsiveness of cells to PRL (Perrot-Applanat et al., 1997; Hu et al., 2001; Meng et al., 2004). Moreover, the differential expression of these receptors is regulated by estrogen in certain tissues (Sakaguchi et al., 1994; Pi et al., 2003). Therefore, we next evaluated whether estrogen regulates the expression of the PRLR in the female TG using an anti-PRLR antibody that recognizes both isoforms (Fig. 3A). Figure 3 shows that estrogen dose dependently upregulates the expression of the long PRLR in the TG of OVX rats $(A, B)$, without having a significant effect on the expression of the short $\operatorname{PRLR}(A, C)$.
Prolactin increases capsaicin-evoked accumulation in intracellular calcium of TG neurons from intact female but not OVX rats

The binding of PRL to the PRLR activates several signaling pathways in nonneuronal cells (Bole-Feysot et al., 1998), some of which are known to be involved in the sensitization of TRPV1 in nociceptors (Cesare and McNaughton, 1996). To evaluate whether PRL sensitizes capsaicin activation of TRPV1, we quantified changes in $\mathrm{Ca}^{2+}$ influx in acutely dissociated TG neurons. The application of $40 \mathrm{nM}$ PRL for 10 min significantly $(p<0.001)$ increased capsaicin-evoked accumulation in intracellular $\mathrm{Ca}^{2+}\left(\left[\mathrm{Ca}^{2+}\right]_{\mathrm{i}}\right)$ levels in neurons isolated from intact female rats (Fig. $4 A, B)$. The PRL-induced increase in the magnitude of capsaicin-evoked $\mathrm{Ca}^{2+}$ influx was observed in $\sim 71 \%$ of all capsaicin-responsive neurons $(\sim 41 \%$ of total neurons). In contrast, PRL had no effect on capsaicin-evoked calcium influx in neurons from OVX control rats (Fig. 4A).

To determine whether PRL augmented capsaicin responses via a PRLR-mediated mechanism, we used a full antagonist $(\Delta 1$ 9-G129R-hPRL) of the PRLR (Bernichtein et al., 2003; Goffin et al., 2005) in 20-fold molar excess and completely blocked the PRL augmentation of capsaicin-evoked calcium influx (Fig. 4C).

Because estradiol induces the expression of the long isoform of the PRLR in the TG from OVX rats, we hypothesized that the loss of PRL modulatory effects observed in OVX TG neurons could be reversed by the in vitro addition of estradiol to those cultures. Capsaicin-evoked iCGRP release experiments were performed to test this hypothesis. PRL significantly sensitized capsaicin-evoked iCGRP release from OVX TG neurons cultured in the presence of $17-\beta$-estradiol (50 nM) for $5 \mathrm{~d}$, whereas the PRL-induced modulation of CAP responses was undetected in OVX TG neurons maintained in the absence of E2 (Fig. 4D).

Prolactin sensitizes capsaicin-induced currents in female but not OVX rat TG neurons

Because the application of PRL rapidly increased capsaicininduced calcium accumulation and neuropeptide release, we next determined whether PRL modulates capsaicin-induced currents $\left(I_{\text {CAP }}\right)$. We used a protocol of repeated application of 100 $\mathrm{nM}$ capsaicin to induce TRPV1 desensitization (Vellani et al., 2001; Bonnington and McNaughton, 2003). The submaximal concentration of capsaicin used was effective in inducing desensitization and permitted the investigation PRL-evoked resensitization or additional sensitization of TRPV1. The application of PRL did not evoke inward currents on its own. However, PRL pretreatment significantly and in a concentration-dependent manner increased $I_{\mathrm{CAP}}$, with a PRL EC $\mathrm{E}_{50}$ of $0.27 \mathrm{nM}$, and a maximal effect was observed at $4 \mathrm{nM}$ in TG cultures from proestrous rats (Fig. $5 A, C$ ). Furthermore, in accordance with data generated 
by $\mathrm{Ca}^{2+}$ imaging and iCGRP release assays, PRL had no effect on the $I_{\mathrm{CAP}}$ recorded from rat OVX TG neurons (Fig. $5 A, D)$.

\section{Prolactin sensitizes heat-evoked currents in female rat TG neurons}

Because TRPV1 is known to be activated by noxious heat $\left(>42^{\circ} \mathrm{C}\right)$ and hyperalgesic agents such as bradykinin (Cesare et al., 1999) and NGF (Chuang et al., 2001; Zhu et al., 2004) sensitize this activation, we next determined whether PRL sensitized heat-evoked currents $\left(I_{\text {heat }}\right)$ in female rat TG neurons. Pretreatment of TG neurons with PRL (40 nM) for 5 min significantly lowered the activation threshold temperature for $I_{\text {heat }}$ from 41.9 to $36.8^{\circ} \mathrm{C}$ (Fig. $6 A, D)$. In addition, we measured the magnitude of the $I_{\text {heat }}$ evoked by $43^{\circ} \mathrm{C}\left(I_{43}\right)$ and $48^{\circ} \mathrm{C}\left(I_{48}\right)$ in neurons pretreated with prolactin or vehicle. PRL significantly sensitized both $I_{43}$ (Fig. $6 B, E$ ) and $I_{48}$ (Fig. $6 C, E)$.

\section{Prolactin induces the phosphorylation of TRPV1 in rat female, but not OVX, \\ TG neurons}

TRPV1 activities are state dependent on phosphorylation status. Thus, interventions phosphorylating TRPV1 are associated with increased responsiveness to capsaicin (Bhave et al., 2003; Zhuang et al., 2004; Mohapatra and Nau, 2005; Mandadi et al., 2006). Accordingly, we next evaluated whether the application of PRL induced an increase in the phosphorylation of TRPV1 in TG cultures. Cultured TG neurons were incubated with PRL (40 nM) or vehicle for $10 \mathrm{~min}$, and then the incorporation of ${ }^{32} \mathrm{P}$ in the TRPV1 protein was measured and analyzed. The application of PRL significantly increased the phosphorylation of TRPV1 $(150 \pm 13 \%)$ in the neurons from intact female rats, whereas there was no change observed in TRPV1 phosphorylation in the OVX rat TG neurons (Fig. 7).

\section{Prolactin sensitizes female rats to capsaicin-evoked} nocifensive behavior in an estrogen-dependent mechanism We demonstrated that PRL modulation of TRPV1 activity is under control of estradiol. To verify that this effect has relevance to capsaicin-induced nociception in the whole animal, we used the corneal wipe test in which capsaicin application induces a brief nocifensive behavior in awake animals (Price et al., 2004; Neubert et al., 2005; Tender et al., 2005). The cornea is a specialized tissue innervated by trigeminal sensory neurons, including TRPV1positive C-fibers (Guo et al., 1999). Immunohistochemical analyses of the cornea from proestrous females reveal fibers that are positive for both PRLR and TRPV1 (Fig. 8A). In female rats in proestrous, PRL pretreatment significantly increased capsaicinmediated nocifensive behavior (Fig. $8 B$ ). However, the OVX vehicle control female rats demonstrated no difference in capsaicin responsiveness after pretreatment with either PRL or vehicle (Fig. $8 C)$. Similar to results obtained from the in vitro studies, estradiol treatment of OVX female rats rescued the PRL enhancement of capsaicin responses (Fig. 8D).
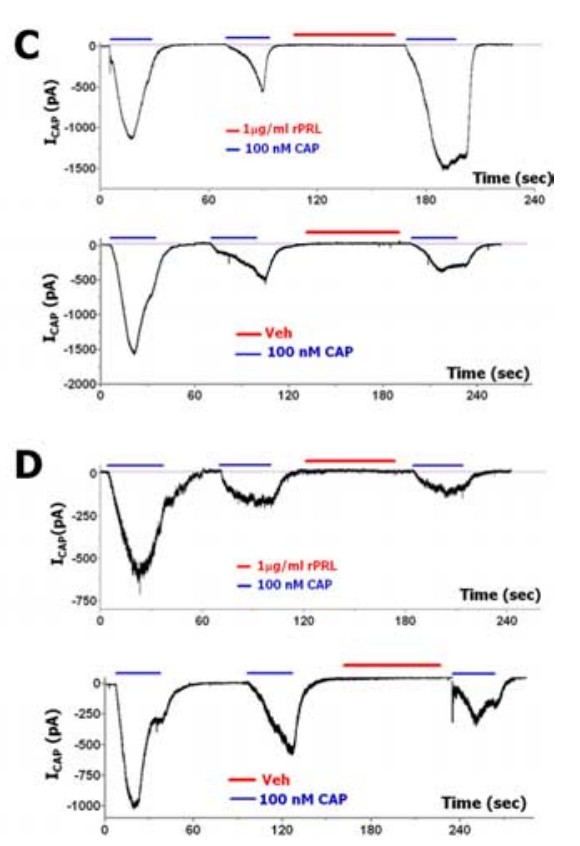

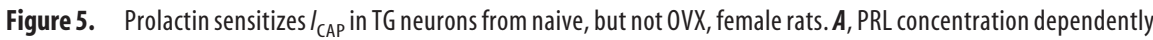
( $60 \mathrm{~nm})$ for $60 \mathrm{~s}$, followed by a single capsaicin pulse ( $40 \mathrm{~s}, 0.1 \mathrm{~nm}$ to $5 \mu \mathrm{m})$. Data are shown as mean $\pm \mathrm{SEM}(n=$ recordings from intact $(\boldsymbol{C})$ and OVX $(\boldsymbol{D})$ female rat TG neurons. Concentration of applied CAP and PRL are indicated. CAP and

$\log [P R L](M)$

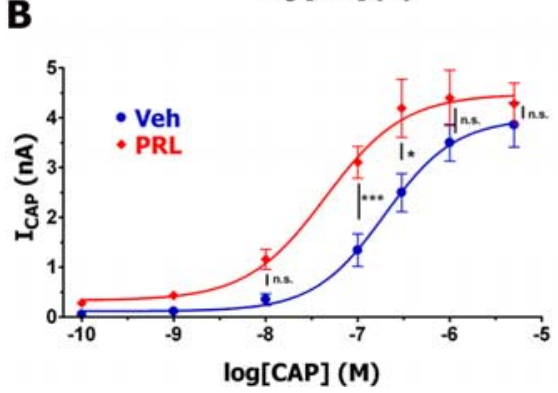

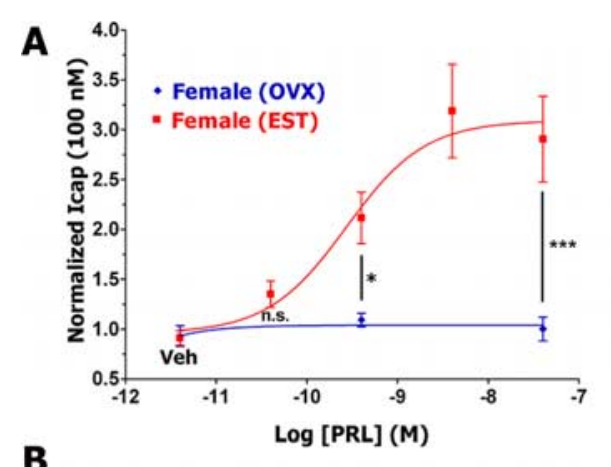




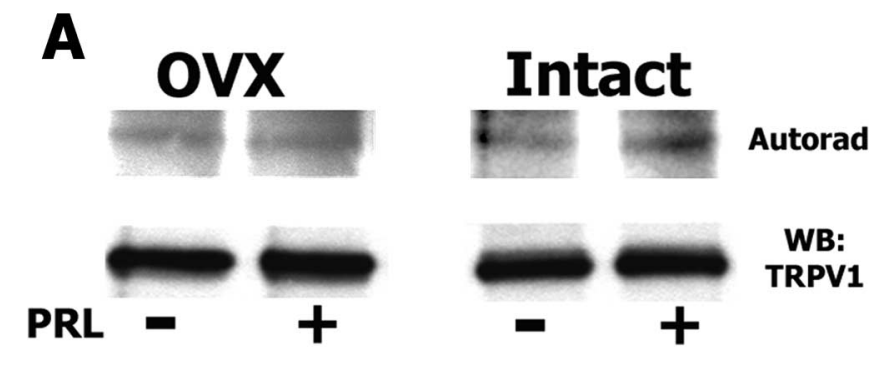

B

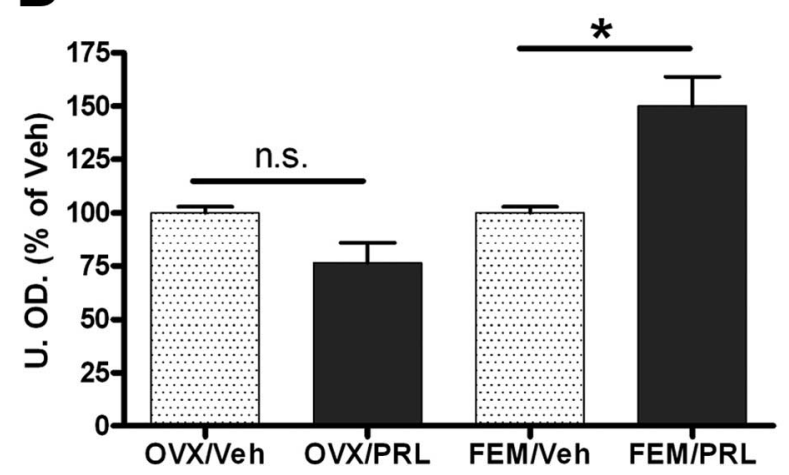

Figure 7. Prolactin induces the phosphorylation of TRPV1. $\boldsymbol{A}$, Representative autoradiograph showing the incorporation of ${ }^{32} \mathrm{P}$ in TRPV1 in acutely dissociated neurons from OVX and proestrous rats after treatment with PRL or vehicle. Proteins were separated in a $15 \%$ SDSPAGE, and the immunoprecipitated TRPV1 was probed with a specific antibody. B, Quantification of ${ }^{32} \mathrm{P}$ incorporation in TRPV1 from acutely cultured TG neurons from OVX and proestrous rats. Autoradiograph uncalibrated OD (U. OD.) was normalized by the TRPV1 U. OD. of each treatment group. PRL significantly induced TRPV1 phosphorylation in neurons from proestrous but, as observed in previous experiments, had no effect in neurons from OVX rats. Data are presented as mean \pm SEM ( $n=3$ per group; ${ }^{*} p<0.05$, two-tailed unpaired $t$ test). Autorad, Autoradiography; WB, Western blot; n.s., not significant; Veh, vehicle; FEM, female.

genes in rat female trigeminal sensory neurons was regulated by estradiol. The PRL gene was found to be most upregulated ( $>40$ fold) in TG neurons of OVX rats treated with estradiol replacement. Subsequent experiments showed the following: (1) PRL is present in sensory neurons in a releasable pool; (2) the expression of PRL as well as the long form of PRLR are regulated by estradiol; (3) PRL-induced sensitization of capsaicin-evoked responses in vitro and in vivo is under control by estradiol; and (4) PRL is able to increase the phosphorylation levels of TRPV1 in cultured TG neurons.

To the best of our knowledge, this is the first report of extrapituitary PRL in peripheral sensory neurons controlled by systemic or local application of estradiol. Neuronal extrapituitary PRL in the rat was first reported in the hypothalamus (Fuxe et al., 1977). Determination of an extrapituitary origin of PRL can be difficult because of the uptake and internalization of circulating PRL by certain tissues (Ben-Jonathan et al., 1996). However, that observation cannot explain the present findings, because PRL mRNA was detected in TG neurons and was significantly upregulated by E2. In addition, the highly restricted expression pattern of PRL in the TRPV1-positive subset of female rat TG neurons argues against a general uptake mechanism. Finally, the finding that the release of PRL from TG cultures was completely abolished when estradiol was removed from the culture media is consistent with a local afferent neuron synthesis of PRL.

To study modulation of sensory neurons by PRL, as the first step, we characterized the expression of the PRLR that mediates PRL actions on TG neurons. Both isoforms of the PRLR are ex- pressed in the female rat TG and colocalize with polymodal nociceptor marker TRPV1 channel in the peripheral trigeminal innervation (cornea). Moreover, the long form of PRLR is regulated by estradiol. TRPV1, which can be activated by noxious heat $\left(>43^{\circ} \mathrm{C}\right)$, low $\mathrm{pH}$, and selectively by capsaicin (Caterina et al., 1997, 2000), plays a crucial role in transducing thermal hyperalgesia induced by endogenous inflammatory mediators such as bradykinin (Ferreira et al., 2004) and NGF (Lewin et al., 1994; Bonnington and McNaughton, 2003). Therefore, we evaluated PRL-induced modulation of TRPV1 activated by capsaicin and heat. The results indicate that PRL concentration dependently increased capsaicin responses using several in vitro and in vivo methods. Additionally, PRL significantly lowered the threshold temperature of $I_{\text {heat }}$ activation and potentiated $I_{\text {heat }}$ currents in TG neurons. Similarly, the decrease in the temperature threshold and potentiation of $I_{\text {heat }}$ magnitude was observed in neurons pretreated with bradykinin (Chuang et al., 2001; Sugiura et al., 2002). The PRL analog $\Delta 1-9-G 129 R-h P R L$ is the only compound that acts as a full PRLR antagonist in all assays tested to date (Goffin et al., 2003, 2005) and completely blocked PRL-evoked sensitization of TRPV1-mediated $\mathrm{Ca}^{2+}$ influx, thus demonstrating that this effect is mediated by the PRLR. In the behavioral experiments, the application of vehicle/capsaicin $(0.01 \%)$ to the cornea evoked a nocifensive behavior that desensitized by $10 \mathrm{~min}$. In contrast, the pretreatment with PRL followed by capsaicin resulted in both greater (potentiation) and longer (resensitization) duration of responses. TRPV1 is known to be desensitized through a $\mathrm{Ca}^{2+}$-dependent tachyphylaxis (Liu and Simon, 1998), which leads to calcineurin-mediated dephosphorylation of the channel (Docherty et al., 1996; Mohapatra and Nau, 2005). Therefore, it could be suggested that PRL is capable of rephosphorylating TRPV1 that was dephosphorylated after capsaicin administration.

Our data indicate that PRL augmentation of capsaicin-evoked responses are E2 dependent because withdrawal of E2 abolished PRL-evoked phosphorylation of TRPV1 and the PRL potentiation/resensitization of TRPV1 responses using both in vitro and in vivo assays. Moreover, the addition of E2 to the TG cultures or to the OVX female rats completely rescued PRL responsiveness. One of the factors determining the response of cells to PRL is the ratio of long/short PRLR. There is a large body of evidence demonstrating that the short PRLR acts as a dominant negative (Cassy et al., 1998; Hu et al., 2001; Saunier et al., 2003; Meng et al., 2004) by the formation of inactive homodimers or heterodimers (Perrot-Applanat et al., 1997) in non-neuronal cells. Interestingly, TG neurons express both forms of the PRL receptors. However, estradiol dose dependently upregulated only the expression of the long form of PRLR. Therefore, the increase in the expression of the long form of the receptor could possibly lead to increased formation of homodimers consisting of the long isoform of PRLR and thus shifting neurons from a PRL unresponsive to a responsive state ( $\mathrm{Hu}$ et al., 2001). Alternatively, estrogen withdrawal could possibly reduce the density of functional PRLR in the plasma membrane. This reduction of receptor density could in turn dramatically decrease PRL functional activity observed in TG neurons from OVX rats.

Locally produced PRL has been shown to be involved through an autocrine/paracrine mechanism in the etiology of breast (Wennbo and Tornell, 2000; Clevenger et al., 2003) and prostate (Wennbo et al., 1997; Lissoni et al., 2005) cancers. In these diseases, PRL and PRLR are expressed in high levels. We have shown that PRL is highly coexpressed with TRPV1 in a releasable pool. This suggests the possibility that locally synthesized PRL could 
act, through a paracrine mechanism, on the nociceptors themselves to sensitize TRPV1. In addition, PRL derived from the anterior pituitary is known to be upregulated by $\mathrm{E} 2$ and is readily available in the plasma. Circulating PRL achieves its peak plasma concentration concomitant with the highest estradiol levels in the plasma in the afternoon of the proestrous day of the reproductive cycle (Ronnekleiv and Kelly, 1988; Arbogast and Ben-Jonathan, 1990). Therefore, either locally produced or circulating PRL might sensitize TRPV1 in an estradiol-dependent manner.

A number of painful conditions, known to be more prevalent in women, have been associated with high circulating PRL levels, such as cluster headaches (Waldenlind and Gustafsson, 1987; Talkad et al., 2004), migraines (Silberstein and Merriam, 1993), systemic lupus erythematosous (Walker, 2001; Mendez et al., 2004; Soto et al., 2004), rheumatic arthritis (Chikanza et al., 1993; D’Ambrosia, 2005), and breast pain (mastodynia) (Theunissen et al., 2005). Bromocriptine, a dopamine agonist and inhibitory of pituitary PRL release, has been clinically used to treat these conditions (Kullander and Svanberg, 1979; Walker, 2001; Talkad et al., 2004). Human breast cancer patients and certain benign breast disorders are often presented with cyclic and noncyclic breast pain mastodynia (BeLieu, 1994). In addition to bromocriptine, short-term tamoxifen treatment has been used to improve prognosis of cyclic mastodynia (Cupceancu, 1985; Moline, 1993). Interestingly, there is elevated expression of TRPV1 in skin nerve endings in human breast carcinoma (Gopinath et al., 2005), and topical capsaicin has been used to alleviate the pain in mastectomized patients (Watson et al., 1989). The present findings that PRL rapidly sensitizes neuronal and behavioral measures of a TRPV1 activity are consistent with the hypothesis that this channel might contribute to certain pain states. However, future research is required to determine whether endogenous PRL contributes to these or other pain conditions.

Collectively, these results demonstrate for the first time that PRL modulation of TRPV1 activity in sensory neurons is under control of estradiol and that the expression of both the ligand (PRL) and receptors (PRLR) is also tightly regulated by estradiol. These findings propose that PRL could contribute to the development of certain pain disorders, possibly including those modulated by estrogen.

\section{References}

Allen AL, McCarson KE (2005) Estrogen increases nociception-evoked brain-derived neurotrophic factor gene expression in the female rat. Neuroendocrinology 81:193-199.

Arbogast LA, Ben-Jonathan N (1990) The preovulatory prolactin surge is prolonged by a progesterone-dependent dopaminergic mechanism. Endocrinology 126:246-252.

BeLieu RM (1994) Mastodynia. Obstet Gynecol Clin North Am 21:461-477.

Ben-Jonathan N, Mershon JL, Allen DL, Steinmetz RW (1996) Extrapitu- itary prolactin: distribution, regulation, functions, and clinical aspects. Endocr Rev 17:639-669.

Ben-Jonathan N, Liby K, McFarland M, Zinger M (2002) Prolactin as an autocrine/paracrine growth factor in human cancer. Trends Endocrinol Metab 13:245-250.

Bereiter DA, Cioffi JL, Bereiter DF (2005) Oestrogen receptorimmunoreactive neurons in the trigeminal sensory system of male and cycling female rats. Arch Oral Biol 50:971-979.

Bernichtein S, Jomain JB, Kelly PA, Goffin V (2003) The N-terminus of human prolactin modulates its biological properties. Mol Cell Endocrinol 208:11-21.

Bhave G, Hu HJ, Glauner KS, Zhu W, Wang H, Brasier DJ, Oxford GS, Gereau RWt (2003) Protein kinase C phosphorylation sensitizes but does not activate the capsaicin receptor transient receptor potential vanilloid 1 (TRPV1). Proc Natl Acad Sci USA 100:12480-12485.

Bole-Feysot C, Goffin V, Edery M, Binart N, Kelly PA (1998) Prolactin (PRL) and its receptor: actions, signal transduction pathways and phenotypes observed in PRL receptor knockout mice. Endocr Rev 19:225-268.

Bolstad BM, Irizarry RA, Astrand M, Speed TP (2003) A comparison of normalization methods for high density oligonucleotide array data based on variance and bias. Bioinformatics 19:185-193.

Bonnington JK, McNaughton PA (2003) Signalling pathways involved in the sensitisation of mouse nociceptive neurones by nerve growth factor. J Physiol (Lond) 551:433-446.

Boutin JM, Jolicoeur C, Okamura H, Gagnon J, Edery M, Shirota M, Banville D, Dusanter-Fourt I, Djiane J, Kelly PA (1988) Cloning and expression of the rat prolactin receptor, a member of the growth hormone/prolactin receptor gene family. Cell 53:69-77.

Cassy S, Charlier M, Belair L, Guillomot M, Charron G, Bloch B, Diiane J (1998) Developmental expression and localization of the prolactin receptor (PRL-R) gene in ewe mammary gland during pregnancy and lactation: estimation of the ratio of the two forms of PRL-R messenger ribonucleic acid. Biol Reprod 58:1290-1296.

Caterina MJ, Schumacher MA, Tominaga M, Rosen TA, Levine JD, Julius D (1997) The capsaicin receptor: a heat-activated ion channel in the pain pathway. Nature 389:816-824. 
Caterina MJ, Leffler A, Malmberg AB, Martin WJ, Trafton J, Petersen-Zeitz KR, Koltzenburg M, Basbaum AI, Julius D (2000) Impaired nociception and pain sensation in mice lacking the capsaicin receptor. Science 288:306-313.

Cesare P, McNaughton P (1996) A novel heat-activated current in nociceptive neurons and its sensitization by bradykinin. Proc Natl Acad Sci USA 93:15435-15439.

Cesare P, Dekker LV, Sardini A, Parker PJ, McNaughton PA (1999) Specific involvement of PKC-epsilon in sensitization of the neuronal response to painful heat. Neuron 23:617-624.

Chikanza IC, Petrou P, Chrousos G, Kingsley G, Panayi GS (1993) Excessive and dysregulated secretion of prolactin in rheumatoid arthritis: immunopathogenetic and therapeutic implications. Br J Rheumatol 32:445-448.

Chomczynski P, Sacchi N (1987) Single-step method of RNA isolation by acid guanidinium thiocyanate-phenol-chloroform extraction. Anal Biochem 162:156-159.

Chuang HH, Prescott ED, Kong H, Shields S, Jordt SE, Basbaum AI, Chao MV, Julius D (2001) Bradykinin and nerve growth factor release the capsaicin receptor from PtdIns(4,5)P2-mediated inhibition. Nature 411:957-962.

Clevenger CV (2003) Role of prolactin/prolactin receptor signaling in human breast cancer. Breast Dis 18:75-86.

Clevenger CV, Kline JB (2001) Prolactin receptor signal transduction. Lupus 10:706-718.

Clevenger CV, Furth PA, Hankinson SE, Schuler LA (2003) The role of prolactin in mammary carcinoma. Endocr Rev 24:1-27.

Cupceancu B (1985) Short-term tamoxifen treatment in benign breast diseases. Endocrinologie 23:169-177.

D’Ambrosia RD (2005) Epidemiology of osteoarthritis. Orthopedics 28:s201-s205.

De Petrocellis L, Melck D, Palmisano A, Bisogno T, Laezza C, Bifulco M, Di Marzo V (1998) The endogenous cannabinoid anandamide inhibits human breast cancer cell proliferation. Proc Natl Acad Sci USA 95:8375-8380.

Docherty RJ, Yeats JC, Bevan S, Boddeke HW (1996) Inhibition of calcineurin inhibits the desensitization of capsaicin-evoked currents in cultured dorsal root ganglion neurones from adult rats. Pflügers Arch 431:828-837.

Fehrenbacher JC, Burkey TH, Nicol GD, Vasko MR (2005) Tumor necrosis factor alpha and interleukin-1beta stimulate the expression of cyclooxygenase II but do not alter prostaglandin E2 receptor mRNA levels in cultured dorsal root ganglia cells. Pain 113:113-122.

Ferreira J, da Silva GL, Calixto JB (2004) Contribution of vanilloid receptors to the overt nociception induced by $\mathrm{B} 2$ kinin receptor activation in mice. Br J Pharmacol 141:787-794.

Fillingim RB, Ness TJ (2000) Sex-related hormonal influences on pain and analgesic responses. Neurosci Biobehav Rev 24:485-501.

Freeman ME, Kanyicska B, Lerant A, Nagy G (2000) Prolactin: structure, function, and regulation of secretion. Physiol Rev 80:1523-1631.

Fuxe K, Hokfelt T, Eneroth P, Gustafsson JA, Skett P (1977) Prolactin-like immunoreactivity: localization in nerve terminals of rat hypothalamus. Science 196:899-900.

Garry MG, Richardson JD, Hargreaves KM (1994) Sodium nitroprusside evokes the release of immunoreactive calcitonin gene-related peptide and substance $\mathrm{P}$ from dorsal horn slices via nitric oxide-dependent and nitric oxide-independent mechanisms. J Neurosci 14:4329-4337.

Gear RW, Gordon NC, Heller PH, Paul S, Miaskowski C, Levine JD (1996) Gender difference in analgesic response to the kappa-opioid pentazocine. Neurosci Lett 205:207-209.

Goffin V, Binart N, Clement-Lacroix P, Bouchard B, Bole-Feysot C, Edery M, Lucas BK, Touraine P, Pezet A, Maaskant R, Pichard C, Helloco C, Baran N, Favre H, Bernichtein S, Allamando A, Ormandy C, Kelly PA (1999) From the molecular biology of prolactin and its receptor to the lessons learned from knockout mice models. Genet Anal 15:189-201.

Goffin V, Bernichtein S, Kayser C, Kelly PA (2003) Development of new prolactin analogs acting as pure prolactin receptor antagonists. Pituitary 6:89-95.

Goffin V, Bernichtein S, Touraine P, Kelly PA (2005) Development and potential clinical uses of human prolactin receptor antagonists. Endocr Rev 26:400-422.

Gopinath P, Wan E, Holdcroft A, Facer P, Davis JB, Smith GD, Bountra C, Anand P (2005) Increased capsaicin receptor TRPV1 in skin nerve fibres and related vanilloid receptors TRPV3 and TRPV4 in keratinocytes in human breast pain. BMC Womens Health 5:2.

Guo A, Vulchanova L, Wang J, Li X, Elde R (1999) Immunocytochemical localization of the vanilloid receptor 1 (VR1): relationship to neuropeptides, the P2X3 purinoceptor and IB4 binding sites. Eur J Neurosci 11:946-958.

Hu ZZ, Meng J, Dufau ML (2001) Isolation and characterization of two novel forms of the human prolactin receptor generated by alternative splicing of a newly identified exon 11. J Biol Chem 276:41086-41094.

Isselee H, De Laat A, Bogaerts K, Lysens R (2001) Long-term fluctuations of pressure pain thresholds in healthy men, normally menstruating women and oral contraceptive users. Eur J Pain 5:27-37.

Isselee H, De Laat A, De Mot B, Lysens R (2002) Pressure-pain threshold variation in temporomandibular disorder myalgia over the course of the menstrual cycle. J Orofac Pain 16:105-117.

Jabbour HN, Kelly PA (1997) Prolactin receptor subtypes: a possible mode of tissue specific regulation of prolactin function. Rev Reprod 2:14-18.

Katusic S, Beard CM, Bergstralh E, Kurland LT (1990) Incidence and clinical features of trigeminal neuralgia, Rochester, Minnesota, 1945-1984. Ann Neurol 27:89-95.

Kullander S, Svanberg L (1979) Bromocriptine treatment of the premenstrual syndrome. Acta Obstet Gynecol Scand 58:375-378.

LeResche L (1997) Epidemiology of temporomandibular disorders: implications for the investigation of etiologic factors. Crit Rev Oral Biol Med 8:291-305.

Lewin GR, Rueff A, Mendell LM (1994) Peripheral and central mechanisms of NGF-induced hyperalgesia. Eur J Neurosci 6:1903-1912.

Lissoni P, Bignami A, Frontini L, Manganini V, Dapretto E, Gardani GS, Vigano P, Strada G (2005) Possible involvement of prolactin in endocrine-resistant metastatic prostate cancer. Int J Biol Markers 20:123-125.

Liu L, Simon SA (1998) The influence of removing extracellular $\mathrm{Ca}^{2+}$ in the desensitization responses to capsaicin, zingerone and olvanil in rat trigeminal ganglion neurons. Brain Res 809:246-252.

Livak KJ, Schmittgen TD (2001) Analysis of relative gene expression data using real-time quantitative PCR and the 2(-Delta Delta C(T)) method. Methods 25:402-408.

Llovera M, Pichard C, Bernichtein S, Jeay S, Touraine P, Kelly PA, Goffin V (2000) Human prolactin (hPRL) antagonists inhibit hPRL-activated signaling pathways involved in breast cancer cell proliferation. Oncogene 19:4695-4705.

Mandadi S, Tominaga T, Numazaki M, Murayama N, Saito N, Armati PJ, Roufogalis BD, Tominaga M (2006) Increased sensitivity of desensitized TRPV1 by PMA occurs through PKCepsilon-mediated phosphorylation at S800. Pain 123:106-116.

Marcondes FK, Bianchi FJ, Tanno AP (2002) Determination of the estrous cycle phases of rats: some helpful considerations. Braz J Biol 62:609-614.

Martin V, Wernke S, Mandell K, Zoma W, Bean J, Pinney S, Liu J, Ramadan N, Rebar R (2003) Medical oophorectomy with and without estrogen add-back therapy in the prevention of migraine headache. Headache 43:309-321.

Mendez I, Alcocer-Varela J, Parra A, Lava-Zavala A, de la Cruz DA, AlarconSegovia D, Larrea F (2004) Neuroendocrine dopaminergic regulation of prolactin release in systemic lupus erythematosus: a possible role of lymphocyte-derived prolactin. Lupus 13:45-53.

Meng J, Tsai-Morris CH, Dufau ML (2004) Human prolactin receptor variants in breast cancer: low ratio of short forms to the long-form human prolactin receptor associated with mammary carcinoma. Cancer Res 64:5677-5682.

Mohapatra DP, Nau C (2005) Regulation of $\mathrm{Ca}^{2+}$-dependent desensitization in the vanilloid receptor TRPV1 by calcineurin and CAMPdependent protein kinase. J Biol Chem 280:13424-13432.

Moline ML (1993) Pharmacologic strategies for managing premenstrual syndrome. Clin Pharm 12:181-196.

Neubert JK, Mannes AJ, Keller J, Wexel M, Iadarola MJ, Caudle RM (2005) Peripheral targeting of the trigeminal ganglion via the infraorbital foramen as a therapeutic strategy. Brain Res Brain Res Protoc 15:119-126.

Patwardhan AM, Berg KA, Akopain AN, Jeske NA, Gamper N, Clarke WP, Hargreaves KM (2005) Bradykinin-induced functional competence and trafficking of the $\delta$-opioid receptor in trigeminal nociceptors. J Neurosci 25:8825-8832.

Perrot-Applanat M, Gualillo O, Pezet A, Vincent V, Edery M, Kelly PA 
(1997) Dominant negative and cooperative effects of mutant forms of prolactin receptor. Mol Endocrinol 11:1020-1032.

Pi X, Zhang B, Li J, Voogt JL (2003) Promoter usage and estrogen regulation of prolactin receptor gene in the brain of the female rat. Neuroendocrinology 77:187-197.

Price TJ, Patwardhan A, Akopian AN, Hargreaves KM, Flores CM (2004) Modulation of trigeminal sensory neuron activity by the dual cannabinoid-vanilloid agonists anandamide, $\mathrm{N}$-arachidonoyl-dopamine and arachidonyl-2-chloroethylamide. Br J Pharmacol 141:1118-1130.

Purves-Tyson TD, Keast JR (2004) Rapid actions of estradiol on cyclic amp response-element binding protein phosphorylation in dorsal root ganglion neurons. Neuroscience 129:629-637.

Riddle O, Bates RW, Dykshorn SW (1933) The preparation, identification and assay of prolactin-a hormone of anterior pituitary. Am J Physiol 105:191-216.

Ronnekleiv OK, Kelly MJ (1988) Plasma prolactin and luteinizing hormone profiles during the estrous cycle of the female rat: effects of surgically induced persistent estrus. Neuroendocrinology 47:133-141.

Sakaguchi K, Ohkubo T, Sugiyama T, Tanaka M, Ushiro H, Nakashima K (1994) Differential regulation of prolactin receptor mRNA expression in rat liver and kidney by testosterone and oestradiol. J Endocrinol 143:383-392.

Saunier E, Dif F, Kelly PA, Edery M (2003) Targeted expression of the dominant-negative prolactin receptor in the mammary gland of transgenic mice results in impaired lactation. Endocrinology 144:2669-2675.

Shingo T, Gregg C, Enwere E, Fujikawa H, Hassam R, Geary C, Cross JC, Weiss S (2003) Pregnancy-stimulated neurogenesis in the adult female forebrain mediated by prolactin. Science 299:117-120.

Shirota M, Banville D, Ali S, Jolicoeur C, Boutin JM, Edery M, Djiane J, Kelly PA (1990) Expression of two forms of prolactin receptor in rat ovary and liver. Mol Endocrinol 4:1136-1143.

Silberstein SD, Merriam GR (1993) Sex hormones and headache. J Pain Symptom Manage 8:98-114.

Sohrabji F, Miranda RC, Toran-Allerand CD (1994) Estrogen differentially regulates estrogen and nerve growth factor receptor mRNAs in adult sensory neurons. J Neurosci 14:459-471.

Somerville BW (1975) Estrogen-withdrawal migraine. II. Attempted prophylaxis by continuous estradiol administration. Neurology 25:245-250.

Soto ME, Vallejo M, Guillen F, Simon JA, Arena E, Reyes PA (2004) Gender impact in systemic lupus erythematosus. Clin Exp Rheumatol 22:713-721.

Sugiura T, Tominaga M, Katsuya H, Mizumura K (2002) Bradykinin lowers the threshold temperature for heat activation of vanilloid receptor 1 . J Neurophysiol 88:544-548.

Talkad AV, Kattah JC, Xu MY, Orth EH, Chang JY (2004) Prolactinoma presenting as painful postganglionic Horner syndrome. Neurology 62:1440-1441.
Tender GC, Walbridge S, Olah Z, Karai L, Iadarola M, Oldfield EH, Lonser RR (2005) Selective ablation of nociceptive neurons for elimination of hyperalgesia and neurogenic inflammation. J Neurosurg 102:522-525.

Theunissen C, De Schepper J, Schiettecatte J, Verdood P, Hooghe-Peeters EL, Velkeniers B (2005) Macroprolactinemia: clinical significance and characterization of the condition. Acta Clin Belg 60:190-197.

Toran-Allerand CD, Singh M, Setalo Jr G (1999) Novel mechanisms of estrogen action in the brain: new players in an old story. Front Neuroendocrinol 20:97-121.

Torner L, Maloumby R, Nava G, Aranda J, Clapp C, Neumann ID (2004) In vivo release and gene upregulation of brain prolactin in response to physiological stimuli. Eur J Neurosci 19:1601-1608.

Tusher VG, Tibshirani R, Chu G (2001) Significance analysis of microarrays applied to the ionizing radiation response. Proc Natl Acad Sci USA 98:5116-5121.

Vellani V, Mapplebeck S, Moriondo A, Davis JB, McNaughton PA (2001) Protein kinase $\mathrm{C}$ activation potentiates gating of the vanilloid receptor VR1 by capsaicin, protons, heat and anandamide. J Physiol (Lond) 534:813-825.

Waldenlind E, Gustafsson SA (1987) Prolactin in cluster headache: diurnal secretion, response to thyrotropin-releasing hormone, and relation to sex steroids and gonadotropins. Cephalalgia 7:43-54.

Walker SE (2001) Treatment of systemic lupus erythematosus with bromocriptine. Lupus 10:197-202.

Warren MP, Fried JL (2001) Temporomandibular disorders and hormones in women. Cells Tissues Organs 169:187-192.

Watson CP, Evans RJ, Watt VR (1989) The post-mastectomy pain syndrome and the effect of topical capsaicin. Pain 38:177-186.

Wennbo H, Tornell J (2000) The role of prolactin and growth hormone in breast cancer. Oncogene 19:1072-1076.

Wennbo H, Kindblom J, Isaksson OG, Tornell J (1997) Transgenic mice overexpressing the prolactin gene develop dramatic enlargement of the prostate gland. Endocrinology 138:4410-4415.

Zacur HA, Foster GV, Tyson JE (1976) Multifactorial regulation of prolactin secretion. Lancet 1:410-413.

Zhu W, Galoyan SM, Petruska JC, Oxford GS, Mendell LM (2004) A developmental switch in acute sensitization of small dorsal root ganglion (DRG) neurons to capsaicin or noxious heating by NGF. J Neurophysiol 92:3148-3152.

Zhuang ZY, Xu H, Clapham DE, Ji RR (2004) Phosphatidylinositol 3-kinase activates ERK in primary sensory neurons and mediates inflammatory heat hyperalgesia through TRPV1 sensitization. J Neurosci 24:8300-8309.

Zinger M, McFarland M, Ben-Jonathan N (2003) Prolactin expression and secretion by human breast glandular and adipose tissue explants. J Clin Endocrinol Metab 88:689-696. 